\title{
Z DZIEJÓW PUBLICYSTYKI PATRIOTYCZNEJ PRZED POWSTANIEM STYCZNIOWYM
}

W Polsce XIX wieku - tak jak i w innych krajach zniewolonych przez obcą whadzę lub rodzimą dyktaturę - w okresach napięć politycznych lub społecznych pojawiały się w większej liczbie wydawnictwa tajne drukowane na miejscu lub szmuglowane z zagranicy względnie z innego zaboru, gdzie chwilowo sytuacja była Iżejsza. Wydawnictwa jawne w jednym zaborze bywały nielegalnymi, bezdebitowymi w innym. Takimi bywały też wydawnictwa emigracyjne. Oczywiście publikacje spoza takiej czy innej cenzury mają i w Polsce i w świecie tradycję wielowiekową, lecz w stuleciu XIX (a także i $X X$ ) zjawisko to $-m$.in. dzięki postępowi w poligrafii - wystappiło ze wzmożoną siłą.

Zdaniem prof. S. Kieniewicza wyjątkowy fenomen w skali już nie tylko polskiej ale i europejskiej stanowiły tu tajne druki z lat 1861-1863 i to zarówno w sensie ich ilości, jak też i długotrwałej systematyczności publikacji ${ }^{1}$. Prasa tajna i ulotki z tego okresu (manifesty, instrukcje, odezwy, proklamacje) doczekały się licznych opracowań a niektóre dokumenty - reedycji ${ }^{2}$.

Analizowano także publicystykę Wielkiej Emigracji różnych kierunków politycznych, poświęcając sporo uwagi m.in. tym pozycjom, które odegrały większą czy mniejszą rolę w wydarzeniach w kraju.

Natomiast mniej pisano o tajnych czy jawnie za granicą drukowanych wydawnictwach (zwartych czy ulotnych) z lat 1861-1863 zabronionych w kraju, a zawierających utwory literackie czy też o treściach religijnych. Zajmowano się tylko utworami wybitnymi artystycznie. Natomiast większość tekstów o których mowa, to na ogół nie była literatura wysokiego lotu. Chodziło w niej głównie o walory propagandowe i agitacyjne a nie piękno formy. Były to utwory religijno-patriotyczne: modlitewniki, śpiewniki narodowe, czasem aktualia, czasem satyra polityczna. Autorzy ich, często anonimowi - stawiali sobie cele utylitarne: umocnić wolę oporu wobec zaborcy i w uproszczony, dostosowany do masowego odbioru sposób przedstawiać cele ruchu narodowego. Znaczenie tych publikacji polega głównie na tym, że odbijają mentalność i poglądy przedstawicieli różnych kierunków politycznych - jak też mentalność ludzi, na których chciano wpływać.

Rejestruja je bibliografie powstania styczniowego ${ }^{3}$ - jednak wiele publikacji, które można było widzieć jeszcze przed 1939 r., dziś już nie istnieje.

Konspiracyjne warunki sprawiały, że były to często druki prymitywnie wykonane, litografie, czy wydawnictwa hektografowane. Lepiej na ogół przedstawiały się zewnętrznie te z zagranicy, przeznaczone do przeszmuglowania do kraju. 
O jednej z takich przedpowstaniowych broszur, drukowanej we Wrocławiu, a bardzo dzisiaj rzadkiej, warto powiedzieć parę słów. Jest to wierszowany utwór p.t. „Polski duch"4, prawdopodobnie w zamierzeniu autora mający oddziaływać na środowisko polskich studentów we Wrocławiu, a może i innych uczelni w zaborze pruskim. Nakład był dość duży jak na owa epokę: $1000^{5}$ lub 1200 egzemplarzy 6 . W tym samym roku autor wydał ją w Paryżu, drukując w drukarni L. Martineta, znanej z wielu publikacji Wielkiej Emigracji.

Wrocławski druk został wydany niestarannie, z licznymi błędami drukarskimi, bez okładki, na lichym papierze. Literackiej wartości ta wierszowana publicystyka nie posiada, natomiast służyć może jako jeszcze jeden głos w przedpowstaniowych dyskusjach, głos bliski zapatrywaniom millenerów czy nawet części obozu białych.

Tekst świadczy o dochodzących do Wrocławia wiadomościach z Królestwa, które zresztą autor określał jako „burdy karczemne szkólne [!!!], tajemne schadzki”. Jest apelem o rozwagę polityczną i pracę dla kraju, gdyż na zryw powstańczy jeszcze nie czas. „I ten dziś zdrajcą, ten dziś nas zmitręża, kto dziś was nagli dobywać oręża". "Tych nie słuchajcie co nie żyją w kraju" nawołuje autor stwierdzając, że nie mogą oni znać wewnętrznych stosunków w Polsce. Akcentuje postulat pracy nad ludem, nad narodowym uświadamianiem, gdyż jak dotąd w walkach przeciw zaborcy "Iud był spektatorem ale nie szczerym, prawdziwym aktorem", co w odniesieniu do znacznej części ludności chłopskiej miało się jeszcze raz sprawdzić w wydarzeniach 1863 r. Autor, który był uczestnikiem wydarzeń poznańskich 1848 r. twierdzi, że chłopi brali w nich udział tylko „z namowy naszej” a nie z przekonania. Jako cel ostateczny wysuwał wolną Polskę gdy "gmach niewoli N[iemców] i M[oskali] jak gmach karciany jednym tchem się zwali".

Nakład został przez wrocławską policję skonfiskowany, broszura nie została więc szerzej rozpowszechniona i jest dziś wielką rzadkością. Z dużych bibliotek posiada ją w swych zbiorach Biblioteka Narodowa i Biblioteka Kórnicka.

Autorem broszury jest najprawdopodobniej Władysław Chotomski, poeta i dziennikarz. Za jego autorstwem przemawiają wcześniejsze próby literackie ${ }^{7}, a$ także tendencja utworu skierowanego preciw L. Mierosławskiemu, którego W. Chotomski, uczestnik powstania poznańskiego 1848 r., był zaciętym przeciwnikiem. Ale są i poszlaki mogące sugerować, iż autorem był jego brat Bolesław, w latach 1860-1862 student uniwersytetu wrocławskiego; policja pruska jemu właśnie przypisywała autorstwo. B. Chotomski w procesie o zakup i przemyt broni dla powstania 1863 r. został obciążony dodatkowym zarzutem o napisanie tej broszu$r^{8}$. Broniąc się wskazał na brata, Władysława jako na autora (Władysław przebywał za granica, był więc bezpieczny). Ponadto akcentował organicznikowskie przesłanie wiersza, w którym nawoływano do pracy a nie szybkiego zbrojnego zrywu. Oczywiście to, co B. Chotomski mówił w swej obronie pred pruskim sądem niekoniecznie musiało być prawdą. Ale stylistyczne pokrewieństwo z wcześniejszymi utworami Władysława Chotomskiego sugeruje autorstwo tego ostatniego i tak też opisano tę pozycję w „Bibliografii polskiej XIX wieku” Karola Estreichera (jun.).

Obaj Chotomscy byli synami ziemianina-literata sprzed 1831 r. Ferdynanda Chotomskiego, który po powstaniu listopadowym znalazł się we Francji i tam ukończył medycynę . Bracia wychowywali się pod Gnieznem w majątku krewnego 
I. Chotomskiego; do szkół chodzili w Poznaniu, Trzemesznie a następnie kształcili się w liceum Henri IV w Paryżu. Przez pewien czas (w 1855 r.) przebywali w Warszawie i byli związani z redakcją „Roczników Gospodarstwa Krajowego"10 , a więc znaleźli się w kręgu idei Andrzeja Zamoyskiego.

Obaj bracia Chotomscy stali się szerzej znani w związku z rolą jaką odegrali w powstaniu $1863 \mathrm{r}$. W uzgodnieniu z emigracyjnymi czynnikami niepodległościowymi założyli w Królewcu wraz z J. Koronowiczem w marcu 1862 r. spółkę ${ }^{11}$ („dom komisyjno-ekspedycyjny"), której celem był zakup w krajach Europy zachodniej broni dla powstańców. Zakupów dokonywał przebywający za granicą (głównie w Anglii) Władysław Chotomski zaś B. Chotomski wraz z J. Koronowiczem i innymi konspiratorami ( $\mathrm{m}$.in. Wojciechem Kętrzyńskim) mieli za zadanie przesyłanie broni do Królestwa. Po wykryciu sprawy przez wladze pruskie B. Chotomski, J. Koror.owicz i inni stanęli przed sądem. Obaj współwłaściciele zostali skazani na kary roku więzienia i pokrycie kosztów sądowych.

Po powstaniu Władysław Chotomski do 1870 r. przebywał za granicą, a m.in. we Włoszech, gdzie opublikował w jęz. włoskim broszurę o wyższości cywilizacji europejskiej nad azjatycką ${ }^{12}$. We Włoszech zdobył stopień inżyniera, a także tytuł hrabiego św. państwa rzymskiego i włoski paszport. Za granicą był przez jakiś czas członkiem dyrekcji Komitetu Emigracji Polskiej w Turynie ${ }^{13}$. Następnie osiadł w Poznaniu, wszedł $w$ środowisko literackie tego miasta, zamieszczał artykuły $i$ drobne utwory literackie w poznańskiej prasie, a w r. 1874 (do września, kiedy pismo przestało wychodzić) stał się właścicielem i redaktorem pozytywistycznego „Tygodnika Wielkopolskiego". W 1879 r. zakupił w Królestwie majątek Gulczyn (gub. płocka) i osiedlił się tam, pisując do płockiej prasy.

Natomiast Bolesław po odsiedzeniu wyroku przebywał we Lwowie, ogłaszał broszury i artykuły z dziedziny nauk ekonomicznych i polityki społecznej, publikując je w zaborze austriackim, ale również pruskim, a następnie także $w$ prasie płockiej, gdyż w 1879 r. - wraz z ojcem - przeniósł się do Królestwa, do Piotrowa, majątku brata Władysława.

Życiorysy obu braci to dość typowy dla XIX stulecia los Polaków - tułaczy, którym działalność niepodległościowa poplątała drogi życiowe, chociaż oszczędziła doświadczeń najcięższych.

\section{Przypisy}

${ }^{1}$ S. Kieniewicz, Przedmowa [W:] Prasa tajna z lat 1861-1863. Cz. 1 Warszawa 1966, s. V. Powstanie styczniowe. Materialy i dokumenty.

${ }^{2}$ Omówienie publikacji z tego zakresu zob. przyp. 1.

${ }^{3}$ Najobszerniejsza w „Bibliografii historii Polski XIX w.", t. 2, cz. III, wol. 2-3, pod red. W. Chojnackiego. Wroclaw 1976, 1980.

${ }^{4}$ Polski duch. Wiersz do polskiej mlodzieży. Wroclawiu [!!!] 1861 [druk.] Neumann, ss. 12; toż: Paryż 1861 L. Martinet, ss. 15, 1 nlb. Prawidlowy opis (wraz z podaniem nazwiska W. Chotomskiego) w: K. Estreicher "Bibliografia polska XIX stulecia". Wyd. 2, t. 3, 1962, s. 185; w wyd. 1 "Bibliografii polskiej" Estreichera (t. 6, s. 115) opis nieścisły: hasło Duch polski (anonimowo) i rok wydania 1869. Podobnie nieścisły opis w "Encyklopedii wiedzy o książce", Wrodaw 1979, hasio Tajne wydawnictwa, s. 2312 (Duch polski 1860).

${ }^{5} \mathrm{~K}$. Estreicher, Bibliografia polska XIX stulecia. Wyd. 2, t. 3, 1862, s. 185. 
${ }^{6}$ Encyklopedia wiedzy o książce, s. 2312.

${ }^{7}$ M.in. „Gorzkie żale płaczacego kosyniera nad swoim ekswodzem L. Mieroslawskim", Poznań 1859 oraz ${ }_{n}$ Poine kwiaty. Poezje...", Poznań 1859, nie licząc utworów w prasie. Pierwszy z cytowanych tu utworów wyszedl pod pseudonimem Sydahw Chochlik.

${ }^{8}$ Der Polenprozess im Jahre 1864 nach stenographischen Berichten (...), Berlin 1865, nr 71, s. 13: posiedzenie $z$ dnia 2 XII 1864 oraz Anklage-schrift (...) wegen Hochverraths, Berlin 1864, s. 399-401. O dzialalności Chotomskich w Królewcu są wzmianki w pracach, m.in. B. Groniowska, Rola Prus Wschodnich w powstaniu styczniowym. "Komunikaty Mazursko-Warmińskie" 1960, nr 1, s. 1-45 oraz Z. Grot, Rok 1863 z zaborze pruskim, Poznań 1963; A. Bukowski, Pomorze Gdańskie w powstaniu styczniowym, Gdańsk 1964.

${ }^{9}$ W. Fidler, biogramy Chotomskich [W:] Polski stownik biograficzny, t. 3, Kraków 1937, s. 432-433 oraz B. Konarska, Polskie drogi emigracyjne, Warszawa 1986, s. 241. Bibliografia prac: K. Estreicher, Bibliografia polska XIX stulecia. Wyd. 2, t. 3, 1962, s. 184-185.

${ }^{10}$ W informacjach o Chotomskich nieściśle cytowany tytuł pisma jako "Roczniki Gospodarcze"; tak w biogramie B. Chotomskiego w "Polskim stowniku biograficznym", t. 3, s. 432 oraz biogramie W. Chotomskiego $w_{n}$ Wielkopolskim slowniku biograficznym", Warszawa 1981 ; bibliografia prac obu braci w $_{n}$ Bibliografii polskiej XIX stulecia" K. Estreichera, wyd. 2, t.3, 1962, s. 183-185.

11 O wystawie zorganizowanej przez spółkę zob. m.in. arykuł w "Korespondencie Handlowym, Przemystowym i Rolniczym" (1863, nr 63, s. $1-3$; nr 64, s. 1-2) p.t. "Sprawozdanie o wystawie rolniczo-przemyslowej w Królewcu Braci Chotomskich i Koronowicza".

12 Due civilisationi..., Venezia 1870 - z dedykacją dla G. Mazziniego, G. Garibaldiego i D. Marin, co wskazuje na demokratyczne i niepodległościowe zapatrywania autora.

${ }^{13}$ Zjednoczenie Emigracji Polskiej 1866-1870, Wroclaw 1972, s. 54, 341. Powstanie styczniowe. Materiały i dokumenty. 